\title{
INTERNATIONALISATION MODELS AND TRAJECTORIES OF GOLD JEWELLERY IN JOHANNESBURG: A CONJECTURAL DISCURSIVE APPROACH
}

\author{
Virimai Mugobo $₫$ \\ Department of Retail Business Management ${ }^{1}$ \\ mugobov@cput.ac.za \\ Muzi Jeremia Manzi ${ }^{1}$ \\ ${ }^{1}$ Faculty of Business and Management Sciences \\ Graduate Centre of Management \\ Cape Peninsula University of Technology \\ Cape Town, South Africa, 7535
}

$\triangle$ Corresponding author

\begin{abstract}
The gold jewellery industry is a lucrative sector. It operates within global consumer international networks. The underpinning models of internationalisation of gold jewellery from a theoretical standpoint, are key in comprehending export competitiveness potential. This means that for any company and country to achieve success, they ought to have competitive dominance in the export market, driven by a particular model. This study established that the main trends that characterise gold jewellery exports are underpinned by an aggressive internalisation thrust, which should be supported by market consolidation; market growth; a new channel landscape to push through the products; market consumption trends, absorption capacity, and global fast-fashion demand of gold jewellery. It emerged in this study, that the gold jewellery sector in Johannesburg has many dynamics that affect the ability of gold jewellery exporters to be competitive on the international market. There is a need to implement internationalisation strategies that include the creation of market linkages, standardisation and adaptation of products and services to the changing global market environment. The objective of this study was to investigate the efficacy of the internationalisation models, adopted by jewellery exporters in Johannesburg. The study used both theoretical and empirical data, obtained from the sector. The key finding from the study is that gold jewellery remains one of the most important export commodities in growing economies, such as South Africa. Exports bring the much-needed foreign currency, yet the sector in Johannesburg has very few corporates and individually owned businesses that are connected to the international markets to optimally exploit the opportunities in this sector. Using the mixed review methodology and empirical field data, the study offers propositions to enhance export competitiveness for companies, operating in developing countries.
\end{abstract}

Keywords: jewellery, exports, competitiveness, internationalisation and policy.

DOI: 10.21303/2504-5571.2021.001833

\section{Introduction}

Developing countries, such as South Africa, prioritise trade in precious metals as a means to earn the much-needed foreign currency. This study argues that gold jewellery conjures up images of affluence - and it is appealing to fashion lovers across the world. In many instances, it is associated with glamour and wealth, especially for the affluent consumers of the products. Essentially, the broader society does not immediately associate their lives with any sector, unless where it connects and impacts positively on their livelihoods, but this does not substitute the important role the gold jewellery sector plays in an economy. This is regardless of the sector being treated as for the affluent class in society. Resultantly, the contribution of the gold jewellery industry to Gross Domestic Product (GDP) is important. The contemporary development thrust of South Africa includes the gold jewellery sector as it generates foreign currency, create employment and boost local production, hence the government value this sector as an important export sector that needs incentives and proactive policies [1]. 
Accordingly, [2] elucidate that exports remain the most popular, prompt, and easiest of all methods for firms to enter international markets. However, in that process, exporting gold jewellery requires resources and an understanding of the gold jewellery international market ecosystem and its dynamics. In addition, [2] postulate that there are few companies with resources that offer a high degree of flexibility for exporting gold jewellery with minimal risk, which implies that for starters, resources to enter the export market are a requirement over and above getting the international markets. This study asserts that gold jewellery international markets have the unique circumstance of high risks. Thus, due diligence is as important as the mitigation of risks and the implementation of policies to prevent leakages, loss, securing the markets and developing market confidence to ensure the generation of revenue for South Africa.

This review of the gold jewellery trade ecosystem has shown that the jewellery export sector is affected by various 'turning points' that influenced the course of the gold jewellery cluster's development in South Africa, and many of these challenges have led to the demise of the broad jewellery clusters in Johannesburg [3]. The available literature and empirical evidence on the internationalisation of gold jewellery exports shows that the sector has significantly changed over time. Gold jewellery internationalisation, while it creates an asset base that households hold in high value [4], its broad-based advantages to the generality of the population have been limited. As a result, the export of gold jewellery remains fundamentally schemed and dominated by a few rich individuals and corporates. However, beyond this, the gold jewellery industry has its far-reaching positive impacts in terms of stimulating industrial manufacturing, and, therefore, the sector is a strategic and important economic activity that adds value to exports earnings and creates jobs, as it does to other African countries, such as Ghana [5]. There is no doubt that in South Africa, the juxtaposition of the country's highly developed gold industry epitomises its dominance in continental and international trade of gold jewellery. The growing interest in the jewellery industry as a vehicle for job creation and economic growth underpins the government's thrust to put policies that support exports - but the central critique is how much of internationalisation of gold jewellery allows participation of the local people? This review alludes to the fact that the internationalisation of gold jewellery export has a long history in central Johannesburg. However, there are gaps in, as far as the supportive international trade infrastructure and policies to assist African-owned businesses to grow. As a result, the internationalisation of gold jewellery exports needs to be re-oriented to be economically and financially inclusive across the value chains. Essentially, to optimally exploit the gold jewellery markets, the government's plans should focus on the right mix of policies that respond to the challenges, associated with gold jewellery exports to the international market by indigenously-owned enterprises. Available literature has shown that such policy and programme gaps impede the internationalisation of gold jewellery exports by the broader members of the enterprising South African society.

The aim of the research study was to analyse the efficacy of the internationalisation models that have been adopted by gold jewellery exporters, based in Johannesburg, South Africa.

\section{Study Methodology}

This study used a systematic literature review. This is a technique whereby literature from published research was abstracted, covering theoretical perspectives on the concept of internationalisation. The review technique in this paper involved a systematic review of literature on internationalisation and qualitative analysis of available secondary data. This qualitative analysis was key as it provided data sets, mainly related to the inductive approach; interpretivism and constructionism [6]. The strategy was to provide non-numerical data to highlight and provide rich detail, insights and perspectives from various authors and perceptions from respondents [7]. Clearly, the qualitative strategy emphasised the questionability of exporters and answerability from policy-makers who create the requisite enabling environment for exporters of gold jewellery in the processes of internationalisation and therefore, the views of how internationalisation models operate and how the various approaches have had an impact as enhancers or barriers gold jewellery export. The integration of literature information and contextual findings was a fundamental step 
in understanding views related to the internationalisation of gold jewellery exports. The extraction of literature data was synthesized analytically in this paper to produce demonstrably valid assessments and assertions.

\section{Results}

\section{1. Defining Internationalisation}

The subject of internationalisation is important in the jewellery industry. Its nature and development should be understood in its context, and essentially, internationalisation denotes the value chain, in which corporates offer products abroad to markets that have interest for them [8, 9]. Internationalisation is a process, by which firms gradually increase the international presence of their brands, which could be a way of exporting to a foreign country, establishing export channels or establishing an out of the country selling subsidiary [10]. Alternatively, it is argued, that internationalisation can be interpreted as both a strategic focus and an organisational culture that forms part of a firm's approach in dealing with its clients, especially towards foreign activities, and should have a clear execution plan of such activities in the chosen foreign market [11].

In any case, a firm's competitive advantage should have a broad geographic scope, in which it enjoys dominance in delivering products. These products attain a global reach apart from satisfying the local market hence this defines its international context $[9,12]$. Furthermore, a firm in its attempt for export dominance can exploit economies of scale and network externalities - which gives it leverage as far as product penetration is concerned in the export markets [13]. Thus, internationalisation occurs when a firm expands its business horizons and activities beyond its domestic spectrum, and this normally involves market intelligence, supply chain competitiveness, development and production of high-quality products that are sold into international markets where they are in high demand [14]. Ideally, the firms that internationalise should operate globally, and they must have the ability to compete on a worldwide scale and succeed at the same time.

It is imperative to note 6 that in their operations, the firms, due to their strategic positioning in specific markets, can be affected by a number of factors in the overall global market place, and they should, therefore, have the capacity to understand market dynamics at all times and change accordingly in line with clients' interests [15]. In doing so, it is fundamental for the corporates to go international, having in mind the importance of competitive advantage, and design strategies on how to withstand competition from others. This is seen as being proactive. There is no room to be reactive, and indeed, being proactive presents stimuli for the corporates to undertake strategy changes, which are based on the jewellery company's interests, and can then enable them to exploit unique competencies and/or market possibilities in order to remain competitive in the market. This internationalisation strategy approach is guided by a number of principles; to fulfil a company's growth and profit ambitions; the aspiration, determination and eagerness of the company management to remain relevant and competitive in internationalising their products and the company's capacity to produce quality products that are ultimately unique or technologically advanced in a specialised field $[14,16]$.

In the current study, the jewellery industry in South Africa has to stamp out competition and make great exploits on the international market by way of digitising the marketing of jewellery brands that distinguish their company products as exceptional from the rest and have a competitive market identity from other competitors; set operating standards for delivering the products in a unique way to distinguish the businesses in the export markets from the rest of the firms globally; set benefits for their clients in order to maintain customer loyalty; and if possible, negotiate tax exemptions on their export businesses and these exemptions can play a major motivating role in ensuring that volumes are delivered into the market and hence more foreign currency earnings for the country.

The provision of tax exemptions, therefore, implies the involvement of government in internationalisation in terms of making sound policies that support exports, and this, quintessentially, allows corporates and exporting individuals to sell their products in the international markets at a lower cost than their competitors, and hence, helps them to accumulate higher profit margins. It is 
imperative to mention, that the jewellery market requires aggression and in some cases where there is fragmentation in the supply chain, some agglomeration is needed to ensure the pulling resources together by individuals and corporates to co-brand, co-produce and co-export to avoid competition in the export market.

Essentially, exporting is one of the mechanisms, through which jewellery from Johannesburg reaches international markets. From the available literature, it is asserted, that with sound policies, this is a way of expansion and spreading economic influence globally $[15,16]$. Thus, exporting ordinarily needs some investment, and it can be easy if government support is provided to assist gold jewellery entrepreneurs to have access to the international markets. In order to compliment this process, the government should put in place a cocktail of implementable international trade policies that are sector-specific is crucial in order to enhance jewellery trade and enhance the industry's global competitiveness.

Challenges abound and are inevitable in any business, especially in the gold jewellery industry, which, among others, include lack of supporting policies, and oftentimes the critical issue of currency fluctuations affects the price competitiveness, which is why agglomeration is important to ensure that small firms and individuals are not disadvantaged by the supplies from huge conglomerates who operate in the same line of business. Operating at a low scale without capitalising on agglomeration, means that small firms, which seldom go beyond exporting stages due to their lack of capital resources and marketing clout will be pushed out of business.

The international market ecosystem has no room for reactive business strategies and jewellery firms that operate in this field inherently face stiff competition. If they react to pressures or threats in the local or foreign markets, they are likely to get out of business. Thus, active export strategy adjustments and innovation are critical and required when looking at the market dynamics to reduce not only competitive pressure, but also avert threats. Consequently, adducing creativity and innovation in quality product development and aggressive digitised marketing and promotion becomes paramount $[14,16]$. There is no doubt, that in the internationalisation of jewellery exports, global competitive pressures will remain in one way or the other, but the most critical aspect to note is for the businesses to come up with strategies of how to remain in business in the face of many corporates internationalising. Thus, beyond the manifold and manifestation of international competition, Johannesburg's jewellery firms can still compete on the international markets, and hence, the gridlocks of restrictive trade barriers and capitalisation of the firms through affirmative government policies are important. This helps firms to switch from one tense market to exporting to other overseas markets that have not been explored, for instance, in the BRICS countries that South Africa is a member of. BRICS stands for Brazil, Russia, India, China and South Africa.

Additionally, many firms aspire to internationalise, and once one does so, the corporate may need to focus on different ways to enter a foreign market often by gathering market intelligence and supplying jewellery products that capture the varying social groups in that marketplace. The whole idea is to inspire market confidence and this point needs to be considered carefully as an entry strategy, which involves more commitment to investing in risk reduction $[14,16]$. There is no magic beyond innovation when selling gold jewellery. Selling of one's product in an international market can be a very spasmodic strategic move because the grand plan can be to brand awareness and then move to the more lucrative markets, and this also takes into account the economic-political- cultural aspects of the market one operates in as information spread fast about your products [17]. As a result of customers sharing information, the gold jewellery products gain leverage in the international markets, and the customers' tastes and preferences can be customised. Therefore, the jewellery corporates in Johannesburg must keep in mind that internationalisation is complex, and would need innovation, creativity and proper market intelligence to at least be relevant and present in the export business. This requires government policy intervention to ensure exports are supported.

\section{2. Presentation of findings: Theoretical Perspective of Internationalisation}

There are several theories, underpinning internationalisation. These include what is popularly characterised as the Uppsala model [17]. This model is based on work, done by Johanson and Wiedersheim-Paul [11]. The basis for the theory of internationalisation was laid by Adam Smith 
and David Ricardo who argued that countries stood to gain the most if each of them focused on the production of goods and services, in which they held a position of competitive advantage [18].

In addition, it is argued, that exports bring about economy-wide productivity returns, and eventually, lead to increased levels of GDP and Per Capita Income (PCI) [18]. More fundamentally, the returns manifest in job creation and stimulation of infrastructure development and technology transfer as foreign markets keep demanding and importing goods and services. In general, the gold jewellery industry has had tremendous industrial processing innovations, which means that the sector has over time evolved to adopt modern and sophisticated technology-based precision processing of the products in a world that has become competitive [19]. For instance, gold jewellery products from China and India, including 'imitations', are produced with high-technology precision, and are globally competitive in the same international markets, such as Europe and the United States of America [20-22].

It is important to note, that there are two distinct pathways, by which a firm can internationalise. This is either organically/incrementally. For an example, the Uppsala internationalisation theoretical framework [14] or following a rapid internationalisation process featuring international new ventures and so-called born-global firms that are from inception internationally inclined. The last category (internationally-inclined) companies have emerged at a global scale from inception as they seek to exploit the huge export markets. In the majority of cases, they are well-resourced, with many of them, having both backward and forward synergies with multi-national companies that give them competitive urge over others and emerging businesses. The competition is usually intense and epitomised by investment in global marketing and promotion, mega television and digital public display advertisements to popularise their brands in the marketplace. Fig. 1 illustrates the pathways for internationalisation [14].

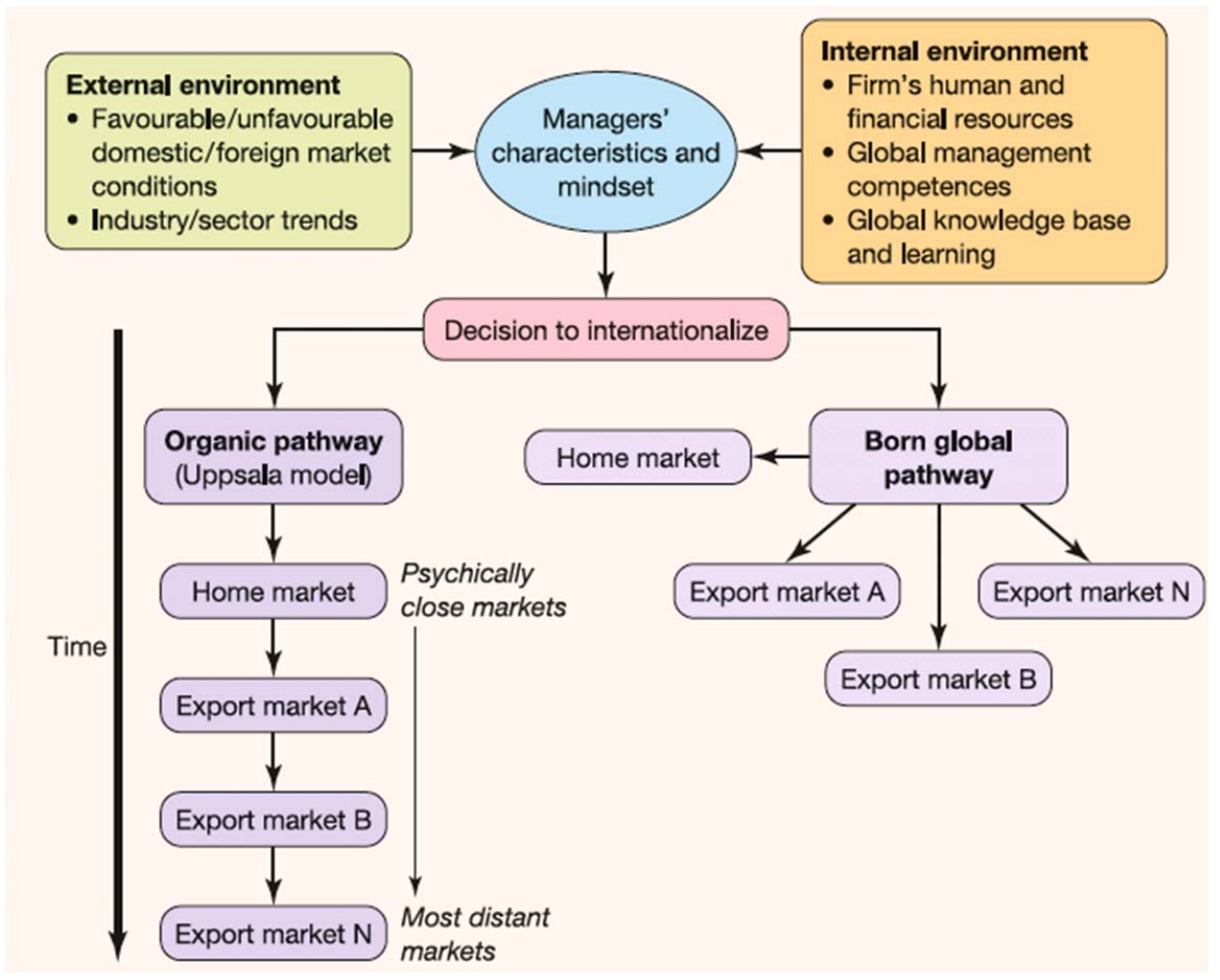

Fig. 1. Pathways for internationalisation [14]

\section{3. The Uppsala Model of Internationalisation}

The Uppsala model was key in dealing with internationalisation. There are disputations around the model, however, internationalisation is a process that evolves as a firm makes foreign commitments as far as investments are concerned and exporting products where they have the best 
competitive advantage [18]. A firm's internationalisation process takes place through successive stages that represent higher degrees of international involvement [11]. This involvement is a strategic move. Ideally, it necessitates corporate executives and policy-makers to converge at the confluence of business strategic planning. This study asserts that the executives and policy makers should reorient export strategies to achieve the best mutually beneficial results. It can be done significantly through increasing export competitiveness to ensure improvements in foreign currency generation; optimise the gold jewellery value chains for employment creation and aggressive agglomeration of the enterprises to increase South African gold jewellery outputs, and products brand visibility in the international market. The strategic stages are summarised in Table $\mathbf{1}$ and followed by Table $\mathbf{2}$, which offers a comparative perspective on various theoretical elaborations of the Uppsala model.

Table 1

Stages of internationalisation [11]

\begin{tabular}{cc}
\hline Stages of internationalisation & Internationalisation activities \\
\hline Stage 1 & No regular export activities \\
Stage 2 & Export via independent representatives (agents) \\
Stage 3 & Establishment of an overseas sales subsidiary \\
Stage 4 & Overseas production/manufacturing units
\end{tabular}

Table 2

Incremental internationalisation models (adapted from )

\begin{tabular}{|c|c|c|c|c|c|c|}
\hline Stages & Bilkey (1978) & Cavusgil (1980) & $\begin{array}{l}\text { (Czinkota \& John- } \\
\text { ston, 1981) }\end{array}$ & (Reid, 1981) & $\begin{array}{c}\text { (Crick, } \\
\text { 1995) }\end{array}$ & $\begin{array}{l}\text { (Leonidou } \\
\text { \& Katsik- } \\
\text { eas, 1996) }\end{array}$ \\
\hline Stage 1 & $\begin{array}{l}\text { The firm is unwill- } \\
\text { ing to export }\end{array}$ & $\begin{array}{c}\text { A firm pursues } \\
\text { domestic marketing } \\
\text { and sells to the local } \\
\text { market }\end{array}$ & $\begin{array}{c}\text { A firm pursues } \\
\text { domestic marketing } \\
\text { and sells to the local } \\
\text { market }\end{array}$ & $\begin{array}{l}\text { The firm is export aware } \\
\text { although still struggles with } \\
\text { identifying opportunities } \\
\text { that may lead to exports }\end{array}$ & $\begin{array}{c}\text { Non-ex- } \\
\text { porters }\end{array}$ & $\begin{array}{l}\text { Pre-export } \\
\text { engagement }\end{array}$ \\
\hline
\end{tabular}

Stage 2 Firm fulfils unsolic- Firm starts searching Firm starts searching ited orders however for information relat- for information relatdoes not explore ing to a market and ing to a market and The firm has an intent to export and is motivated to Passive Initial export further opportunities evaluates feasibility evaluates feasibility to export of pursuing exports of pursuing exports

Stage 3 The firm explores Firm starts exporting Firm starts exporting The firm tries out exporting Active Advanced the feasibility of to a country nearby to a country nearby exporting pursue exports exporters

and begins to learn from the experience

Stage 4 The firm exports ex- Firm pursues exports Firm pursues exports The firm begins to evaluate perimentally to one to more countries to more countries the results of previous export or a few markets

Stage 5 The firm is an expe- Firm begins to Firm begins to rienced exporter to decide regarding the decide regarding the selected markets allocation of resourc- allocation of resources to both local and es to both local and international markets international markets pursuits

The firm begins to accept exports and decides on whether to continue exporting or not

Stage 6 The firm explores possibilities of exporting to additional markets

From the above summary, the Uppsala internationalisation model clearly shows that firms enter markets over extended periods, grounded on their knowledge base, starting first with markets closest to them and later, after undergoing some learning, venture into other more distant markets, with the firm having the prerogative to enter a certain export market or not [23]. [24] advance a new theoretical premise, which suggests that some firms manage to become global players from inception, thereby bypassing the various stages of internationalisation. This is particularly true for 
high technology firms that have seen no need to pursue a business model with an initial domestic focus before going overseas [24].

More interestingly, is the fact that in a globalising world, embracing technology helps enterprises to easily internationalise if they embrace technology and boost production to not only produce quality jewellery, but have access the markets [25]. As such, in Johannesburg, most of the gold jewellery enterprises have since realised the importance of technology in marketing. This study notes that it is the reason, why they have gone digital to increase their market share. It has become the norm rather than exception that most of the enterprises, realise that without the use of technology, the growth of gold jewellery market will fundamentally be stunted. Consequently, to survive the tough global competition, most gold jewellery individuals and corporates have digitised their advertising and embraced technology in jewellery processing. With the right mix of policies, certain stages in the internationalisation process can be leap-frogged by some enterprises [26]. The main observation is that this requires governments to put into place policies that support the internationalisation of gold jewellery exports. It is important to note, that there is a new wave of firms that are technology-driven in the internationalisation process that fosters quick business deals across the globe [27].

In order to understand the context, it is imperative to mention, that the proven alluring nature of gold jewellery from South Africa's Johannesburg insofar as the quality is concerned, is affirmed by the uptake of gold jewellery with the potential of dominating international market [28]. Consequently, jewellery from Johannesburg acts as a catalyst for economic regeneration, employment creation and revenue generation through increased exports that have earned South Africa foreign currency with the total gold exports (including gold jewellery products) accounting for $\$ 4.6$ billion (1.6\%) of the global total, in which the country was number 15 [29].

This study acknowledges that gold jewellery firms in Johannesburg have tended to adopt a more realistic interpretation of the enterprise approach in terms of pushing products into the market. They managed to find the export trajectory based on their understanding of the markets, use of technologies in processing and have also gone digital in the marketing of their products. The findings have further shown the immense competitive advantage of technologies and digital marketing, which in contemporary times play a critical role in internationalisation. God jewellery industry in Johannesburg is now characterised by efforts to increase its competitiveness through the promotion of co-operation and network ties. While debatable, it has to be noted, that in South Africa, the Gold Jewellery Council of South Africa has been promoting exports to various global consumers. However, confidence in gold jewellery has been met with stiff competition. There are other competing supply chains from countries, such as India and China [30].

However, it is important to note, that that the gold jewellery exporters from Johannesburg maintain high-quality levels and have managed to maintain the gold jewellery emotional and economic value, because without doing so, the industry in terms of exports, would have declined. Essentially, the import challenges abound within the global gold economy as manufacturers in other countries are more capitalised in terms of their jewellery processing capabilities, training and technologies are being robustly adopted while those in Johannesburg seem to be lagging. This results obviously in the local gold jewellery manufacturing industry lagging, which, in turn, reduces its exports capacity and competitiveness.

One of the key points is that since 1994, there is evidence that a great deal of money was poured and spent on training gold jewellery manufacturers in South Africa, mainly in Johannesburg. However, this was not followed up with a competitive parallel initiative to simultaneously stimulate growth, especially in exploiting the export market to ensure that the manufactured gold jewellery was absorbed by the international market. At this point, the country was still trying to find its feet after decades of apartheid-induced sanctions. To this end, training initiatives and funds are still focused on promoting traditional hand-made jewellery manufacturing - which in itself has limitations as other countries particularly China and India have taken over the international market by producing jewellery using technology-driven manufacturing processes, which not only accelerates production, but also improve the quality of the products [31]. This study, therefore, argues that even if the South African gold jewellery manufacturing sector introduces technologically ad- 
vanced manufacturing systems, it remains a challenge when it comes to having the requisite skilled individuals in the specialised, high-value gold jewellery processing market due to lack of skills. Consequently, the effective internationalisation and competitiveness of the gold jewellery sector in Johannesburg continues to be under immense pressure.

\section{4. The network model}

The network model is key to understanding the internationalisation process. The business network view assumes that the market represents networks of relationships that link firms in varying dimensions of interdependence, providing opportunities for learning and building trust and commitment, the cornerstones of any internationalisation effort [31]. Markets are a system of social and industrial relationships, which may be among customers, suppliers, competitors, family and friends alike [32]. Essentially, the established business networks play a major role in a firm's foreign market identification process [31].

As alluded to above, these networks are formed at various levels and create a web of connections that are wide and broad. In gold jewellery, some of the manufacturers do not solely rely on technology, but indeed make use of both business and family connections to the consuming markets. One of the most important aspects of gold jewellery trade networks is that trade in many cases is a typical luxury to specific royal families and celebrities, who, in their right, constitute a huge global niche market [33]. To this end, many entrepreneurs tend to rely on these business networks, which make it harder for others to enter these networks unless one is connected to the business network of the niche market and individuals who are the consumers of the gold jewellery markets. Additionally, developing the market relationship is no easy task as in the majority of cases it depends on who you know and how long your relationship has been to command market confidence.

Having looked at the business network model and the Uppsala model, it can be mentioned, that although the Uppsala model as conceived in the mid-1970s established the foundations of internationalisation theory, subsequent developments in the industrial landscape have underlined the explanatory importance of the business network model in the internationalisation process [34]. The network internationalisation process model comprises of state and change aspects, as depicted in Fig. 2 below [31], and the argument this paper proffers is that firms change as a result of lessons, learned from operating in international markets, as well as through the level of commitment they make in the foreign market to cement their standing and relationship that govern current and future collaboration [31].

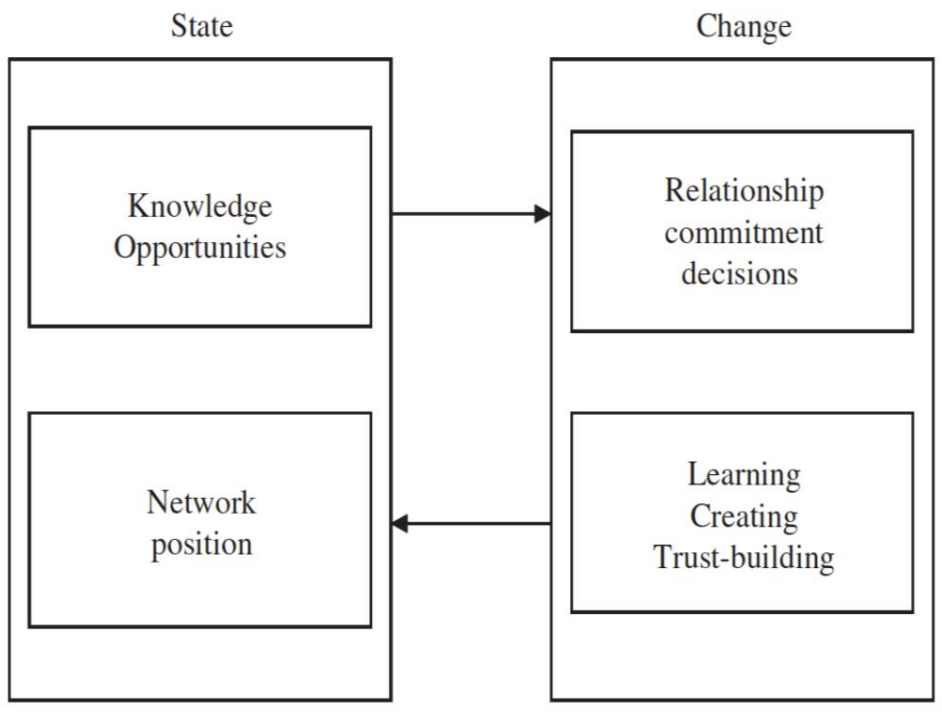

Fig. 2. The internationalisation process of the firm [32] 
In essence, the network of the internationalisation model, has parameters, governing the relationships of the players in the network. These parameters range from internationalisation as an incremental process of knowing the clients. Similarly, this can be likened to knowledge accumulation, which this paper argues, determines gold jewellery export competitiveness that a firm can undertake at three different levels of being a manufacturer or producer of gold jewellery, being a supplier into the international market and at times subcontracting, coordinating subcontractors, and managing the gold jewellery supply chain ecosystem [35]. These network typologies are argued to be grounded in relationships, knowledge and the nature of the customer-supplier interaction that a local gold jewellery firm in Johannesburg creates and leverages for global export competitiveness. The state aspects are critically important since this is the realm of trade policies and determines the direction of the firm as far as its growth trajectory is concerned. Indeed, it is expected, that the state, through laws, policies and statutory measures, regulates the conduct of business. This can enhance or inhibit the potential for growth of any enterprise. However, without the firm's resources, no matter how flexible is the environment that the state creates, their efforts to export and internationalise will be futile if there are no adequate resources. To this end, the next section examines the resource-based model.

\section{5. Resource-based view}

Manufacturers' attainment of international success in pursuing export opportunities is commensurate with the amount of resources they commit [33]. Unlike large manufacturers, small and medium firms, which are most common in Johannesburg, are confronted by resource scarcity. Consequently, the export enterprise becomes not only unaffordable, but too risky. Instead, small gold jewellery firm owners concentrate their efforts on gaining a local market share as opposed to the export market. The majority of them rely on hand-made jewellery, which does not compete well on the export market where many firms concentrate on selling technology-produced jewellery [31].

The resource-based view maintains that firms can derive sustainable competitive advantage in the local and export markets from offering products of value that are rare and difficult to emulate [34]. The gold jewellery sector in Johannesburg is structured in such a manner that the trajectories of internationalisation would call for more external linkages, without which firms cannot be able to make a positive impact as far as exports are concerned, especially the emerging black businesses. Thus, the external versus the internal structure of the gold jewellery exporting firms would require serious synergistic relationship-building to exploit the optimum benefits from internationalisation that are highly dependent on business networks. These forward and backward relationships are based on knowledge and business ethics with an export success orientation.

\section{6. EPRG Model}

The EPRG model is an ethnocentric, polycentric, region-centric and geo-centric framework, used by firms as a strategic tool to pursue internationalisation [34]. The EPRG model is used in international marketing to determine a company's strategic orientation, an important factor since costs and profits differ in line with a firm's orientation [34,35]. Ethno-centric orientated companies tend to maintain a strong link to their home-based approaches, methods, and values, to the extent of replicating their marketing mix in the host country, whereas those with a polycentric approach will endeavour to adapt their marketing mix to meet local conditions. Regio-centric inclined firms tend to maintain a similar marketing strategy intra-regionally, while geo-centric oriented companies tend to evaluate the situation and create products to be positioned in line with the various markets' demands globally [34]. The geocentric orientation assumes that global markets comprise of similarities and differences, recognition of which enables the creation of an international strategy to exploit the similarities between markets for the benefits of the firm [36].

\section{7. The Eclectic paradigm}

The eclectic paradigm recognises that firms can internationalise through international production that is, establishing production capacity in a foreign country as a way of entering that market [37]. Furthermore, the eclectic paradigm of internationalisation represents foreign production, 
which is the final stage of the Uppsala internationalisation theory [38]. The eclectic paradigm is also referred to as the ownership-location-internalisation (OLI) framework [36]. As [37] professes, advantages accrue to a firm that embarks on international production and these include ownership, location, and internalisation. The disadvantages of this paradigm range from not speaking the local language to having limited knowledge of local customer demands [37].

Multinational companies' ownership of firm-specific competencies, such as patents, trademarks, technology and brand names, tends to give them an edge over local firms in servicing a particular international market [39]. These ownership advantages allow a firm to establish a presence in another country to take advantage of resources, such as minerals, that are abundantly located in that country. Firms can accrue profits by exploiting both their ownership and location advantages through internationalisation, as opposed to the adoption of unrelated third-party market activities, such as leasing, licensing, franchising and the formation of joint ventures [39]. Fig. 3 below, summarises Dunning's OLI framework as it relates to foreign market choice and entry mode.

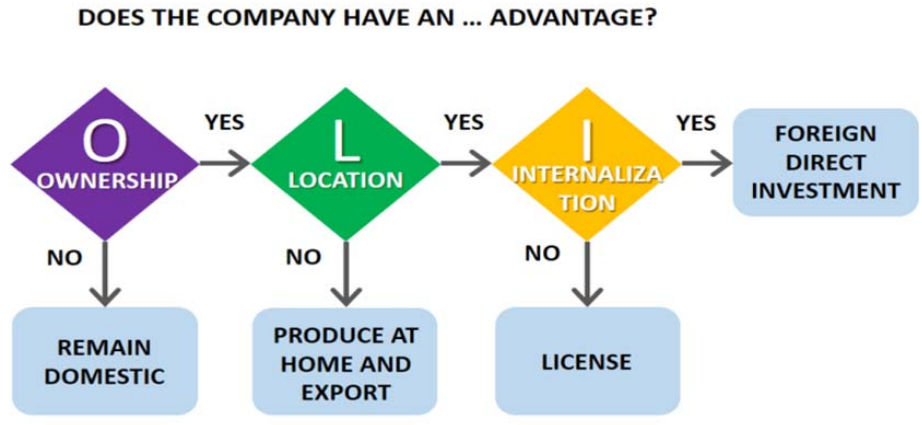

Fig. 3. Advantages, needed when entering foreign markets [40]

\section{8. The Transaction Cost Analysis (TCA) model}

This model relates to the cost of the business-based model. The central critique is that any firm that pursues any export opportunity is based on rational costs implications, in which there should be an advantage in the value chain. Thus, Transaction Cost Analysis (TCA) as a theory predicts that the internationalisation of business activities within a firm will be pursued to the extent that the costs, associated with such activities, continue to provide a cost advantage [36]. This notion is supported by [41] who argue that the use of TCA by firms can assist them to decide whether to conduct marketing and distribution activities abroad on their own or employ the services of agents to reach wholesalers, retailers or final customers. It is further noted, that firms pursue vertical integration solely to reduce transaction costs, or else they opt to outsource the activity and locate it where it can be done cheaply [36].

\section{9. Motivation for internationalisation}

Apart from the opportunities for profit and growth, offered by foreign markets, [42] identifies (among other stimuli) access to government-sponsored export promotion programmes as one of the reasons why firms embark on export programmes. Stimuli comprise any factors that trigger a firm's decision to start exporting; while exporting is beneficial to manufacturers, the majority of them do not pursue exports due to inadequate stimulation [43]. Stimuli to export are likely to differ depending on the export destination [43]. The following are the possible export stimuli [43]:

- having an export-oriented manager within the company;

- being presented with an unsolicited export order;

- firm-level managerial expertise;

- opportunity to diversify markets as a risk mitigation factor;

- pursuit of opportunities for more profit and growth opportunities in export markets;

- firm's ability to adapt current product offerings for export markets;

- attractive and accessible government export incentives; 
- government-sponsored export promotion programme awareness;

- available production capacity;

- favourable import tariffs by export destination;

- local currency depreciation against foreign target markets currencies;

- favourable product regulations in target countries' markets;

- attainment of economies of scale due to additional orders to fulfil export orders;

- loss in local market share due to increased competition;

- local market saturation;

- ownership of unique and innovative products; and

- opportunity to reduce stock in hand.

[44] classifies motives for internationalisation as either being proactive or reactive. A company's proactive approach to internationalisation reflects a change in strategy and hinges on the company's desire to exploit its unique product offerings or pursue opportunities, presented by an export market. Reactive motives, on the other hand, are a consequence of pressure, exerted on a company, emanating from either a local or foreign export market, resulting in the company, having to change over time [36]. As presented in Table 3, [36] provides a list of export stimuli, comparable to that of [42], but divided between proactive and reactive stimuli.

Table 3

Motives for starting exports [36]

\begin{tabular}{cc}
\hline Proactive motives & Reactive motives \\
\hline - Pursuit of profitability and growth prospects & - Competition \\
- Managerial capacity & - Saturated or small local market \\
- Unique product offerings & - Production capacity underutilisation \\
- Export opportunities and information & - Unsolicited export orders \\
- Attainment of economies of scale & - Deal with market seasonality \\
- Favourable taxation & - Closeness of export markets
\end{tabular}

Other scholars have defined these proactive and reactive motives as pull and push factors, respectively [45]. A different classification identifies internal and external stimuli, as reflected in the more elaborate taxonomy of such factors that appears as Fig. 4 below [43, 44].

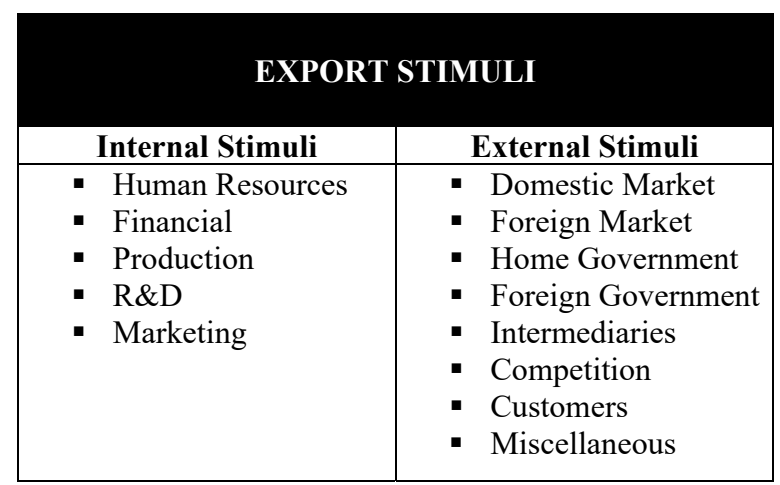

Fig. 4. Classification of internationalisation factors [43].

\section{10. Entry mode}

[45] identifies exporting, turnkey projects, licensing, franchising, joint venture establishment, or the creation of a new subsidiary in a foreign market as the methods, through which firms can internationalise. While each model has advantages and disadvantages, exporting remains the most common, prompt, and simplest way for firms to internationalise [46]. Exporting requires fewer resources and is both flexible and less risky; it eliminates the need for the substantial capital 
outlay, associated with the establishment of a factory in a foreign market and provides a platform for learning more about the target market [44]. At the same time, the firm's manufacturing home base may not necessarily be the most cost-effective location, from which to manufacture for export, and exporting has other pitfalls, such as high transport costs, tariff barriers, as well as complete loss of control over the firm's marketing if such an activity is outsourced to an agent in the export market [44].

\section{11. The importance of jewellery exports at the firm and national levels}

[47] assert that there are varying degrees of benefits to be derived by companies from export incentives, depending on their stage of involvement on the export continuum. During the early stages, export incentives provide businesses with information on how to become exporters and thus motivate them to export [48]. They further state that in the second and third stages, businesses obtain more information about exporting as well as assistance in conducting export business within the export market. Despite the benefits listed above, [49] find the bureaucracy, associated with government incentives, to be a challenge for established exporters, unlike emerging exporters who seem willing to tolerate it in order to access such support.

[44], as well as [50], attest to the fact that exports at the firm level result in growth and increased competitiveness, with resultant increases in levels of productivity, innovation, and performance. This is supported by [51], who lists among the benefits for exporting as including efficiency enhancement of production capacity, stimulation of product or service diversification, as well as reduction of risk. In order to achieve export-led economic growth, countries have to implement export promotion strategies as China has done [52]. Research demonstrates that exporting firms enjoy a marked advantage over non-exporting firms, showing higher levels of growth, skills and capital intensity, and paying their employees more on average. The benefits of exports include a resultant increase in domestic employment, a source of foreign exchange, the creation of backward and forward economic linkages, and the development of new technologies, resulting in an overall increase in the standard of living of the people and the transformation of the communities as well [43].

\section{12. Internationalising gold jewellery exports and value chains}

One of the key findings of this study is that the gold jewellery sector is predominantly driven by corporates that have no links with the majority of the smaller firms. As such, [31] noted that successive Jewellery Council of South Africa chairmanship has not been occupied by an African. As such, capital investment in the gold jewellery sector tends to follow a racial trajectory that should change to be more inclusive and accommodative, including access to capital for new entrants to effectively enter the export market. Ideally, the governance structure of local gold jewellery in its current state affects the participation of smaller black-owned gold jewellery entrepreneurs who want to participate in the global value chains. It is imperative to state, that the starting point of the gold jewellery internationalisation process should be the expansion of the export support schemes to enable broad-based participation of many emerging enterprises. The jewellery export management and governance system, therefore, would need to be upgraded to ensure lead firms in Johannesburg and its current institutions' shape and organise the export supply chains to effectively internationalise. Therefore, upgrading the trajectory in terms of exports should be complemented by having strategies for the firms to improve and maintain their thrust to synergies efforts, have structures that support global export value chains as this is where most earnings are [51]. Therefore, to improve operability, the jewellery industry should not only be confined to gold jewellery, but should be able to appreciate the value chain and develop the flexibility of moving into higher-value activities that may not necessarily be linked to gold jewellery manufacturing.

To this end, the gold jewellery firms need to acquire new technological capabilities, knowledge, market linkages, assets, workers training and build brand reputations that enhance market confidence, and by so doing, they can easily internationalise. More importantly, there is need to also upgrade in terms of coming up with the right mix of government policies, institutions that facilitate rather than being a barrier to internationalise, and build corporate strategies and worker skills that also support the internalisation of products in a market that has become tremendously competitive [51]. At the same time, it is imperative to assert, that in any internationalisation pro- 
cess, the critical issue of sustainability, affordability and profitability of the gold jewellery sector is important. It is without rebuttal, that most black emerging gold jewellery firms in Johannesburg face growth challenges - and this paper has concluded that there is a need to also look at both the economic and social upgrading, which should be reached through policies that affirmatively support marginalised groups. [51] proposed four comprehensive types of economic upgrading that are key in this paper and these have a bearing on the critical elements that can be applied in the gold jewellery industry. These are listed as:

1. Process upgrading, which demands that changes should take place in the production processes, to transform the inputs (gold in this case) into outputs more efficiently (gold jewellery fashion and otherwise).

2. Product upgrading, which involves largely the introduction of more advanced product lines. This is more innovation-driven after robust market analysis and understanding the dynamics of the tastes of the clients, their preferences and habits, which should be incorporated in coming up with product designs.

3. Functional upgrading is when the gold jewellery firms ultimately change the mix of activities they perform. This can be in the form of moving towards higher value-added tasks through acquiring new functions in the chain, for example, one can produce, create the marketing platform, form the source market agency system and the distribution outpost, which they have control over and are able to manage.

4. International chain upgrading implies that entry into a new international value chain in terms of exports should ordinarily leverage the knowledge and skills, acquired in the current existing value chains. There is no substitute to experience, either learning from past failures or successes, all of which are important in the design principle to ensure that the risks are eliminated and the opportunities and strengths are maximised to achieve the right mix of results.

In the final analysis, a credible argument of this paper is that the process of upgrading trajectory is centred on change. This change in the assembling industry is akin to this subject matter and in commodity global value chains would entail moving from simple ways of doing things to complex processes that make the entire sector fully inter-connected and more integrated to ensure a competitive edge in the market place [53]. Otherwise, without this strong creativity and innovation, especially in the gold jewellery sector, there is a likelihood that the process to internationalise gold jewellery firms in Johannesburg would be a tough and unpalatable enterprise. Consequently, the paper observes that the right mix of gold jewellery policies and financing mechanisms to adopt smart technologies are important for the growth of the gold jewellery sector to be highly competitive.

\section{Discussion}

Many firms in Johannesburg have a valid expectation to earn more money and this is manifested in the challenges the local market is facing, which are characterised by low earnings, the decline in the local uptake of fashion-designed gold jewellery and change in focus to livelihood issues rather than luxuries. As a result, manufacturers of gold jewellery have been forced to internationalise. At the time of this study, they were focusing on different ways to enter foreign markets. It is imperative to mention, that it was often noted that the firms were at varying stages of positing themselves to exploit the export markets, but they were facing enormous barriers in this endeavour.

Some of the barriers were more managerial. Others were related to export market entry strategies as each strategy that was needed, would involve investment in terms of financial capital, human capital and more importantly, commitment and risk assessment from a marketing intelligence point of view. However, one of the key barriers in this respect is noted in the literature as 'control and potential profits' that one would realise from making such a decision, based on one's due diligence $[15,16]$. At the policy level, the obvious critical policy dimensions mentioned related to export licensing, product certification and standardisation and supply contract negotiations. In this case, the black-owned firms lacked in greater measure the capacity to fulfil most of the requirements. Such barriers, therefore, put pressure and risk on these emerging firms $[16,36]$. 
Consequently, the gold jewellery sector's competitiveness is reduced and limited in its efforts to internationalise, thereby forcing the sector to focus on the domestic market, which, by its very small size, is saturated, with less buying power and hence, restrict the growth of the gold jewellery sector in South Africa. From a broad conceptual perspective, the Table 4 below provides a comprehensive analysis of the barriers of internationalising gold jewellery exports in Johannesburg, and these are derived from existing challenges that have been identified.

Table 4

Selected export-related trade barriers to internationalise

\begin{tabular}{|c|c|c|}
\hline (Bilkey, 1978) & Onkvisit \& Shaw, (2004:53) & Czinkota \& Ronkainen (2007:44) \\
\hline $\begin{array}{c}\text { - Perceived high risk } \\
\text { - Insufficient capital } \\
\text { - Protective foreign government regulations } \\
\text { - Inadequate/inappropriate distribution } \\
\text { channels } \\
\text { - Insufficient knowledge of marketing } \\
\text { opportunities in foreign market } \\
\text { - Difficulties in understanding foreign } \\
\text { business practices } \\
\text { - Difficulties in conforming to foreign prod- } \\
\text { uct standards and specifications } \\
\text { - Difficulties in collecting payments from } \\
\text { foreign customers } \\
\text { - Inadequate representation in foreign } \\
\text { markets } \\
\text { - Lack of foreign marketing connections }\end{array}$ & $\begin{array}{c}\text { - Import policies } \\
\text { - Standards, testing, labelling, and certi- } \\
\text { fication } \\
\text { - Government procurement policies (local } \\
\text { content regulations) } \\
\text { - Export subsidies } \\
\text { - Lack of intellectual property protection } \\
\text { - Services barriers } \\
\text { - Investment barriers } \\
\text { - Anticompetitive practices tolerated by } \\
\text { foreign governments } \\
\text { - Trade restrictions affecting electronic } \\
\text { commerce } \\
\text { - Other barriers such as bribery and } \\
\text { corruption }\end{array}$ & $\begin{array}{c}\text { - Special import authorisation } \\
\text { - Restrictions on data processing } \\
\text { - Voluntary export restraints } \\
\text { - Advance import deposits } \\
\text { - Taxes on foreign exchange deals } \\
\text { - Preferential licensing applications } \\
\text { - Licensing fees } \\
\text { - Excise duties } \\
\text { - Discretionary licensing } \\
\text { - Trade restrictions on e-commerce } \\
\text { - Anti-competitive practices } \\
\text { - Country quotas } \\
\text { - Testing and labelling } \\
\text { - Seasonal prohibitions } \\
\text { - Health and sanitary prohibitions } \\
\text { - Certifications } \\
\text { - Foreign exchange licensing } \\
\text { - Barter and countertrade requirements } \\
\text { - Customs surcharges } \\
\text { - Stamp taxes } \\
\text { - Consular invoice fees } \\
\text { - Taxes on transport } \\
\text { - Export subsidies }\end{array}$ \\
\hline
\end{tabular}

Table 4 above summarises barriers to internationalisation that have a phenomenal impact on the growth of the gold jewellery sector, as they do also have with other sectors of South African. Consequently, there is strong evidence of the general slowing down of gold jewellery exports in the lucrative global markets while the local market also remains depressed in terms of its buying power. The increasing competition on a global scale due to high-quality products, coming from technologically-advanced countries, means that there is a need for the government and the private sector in South Africa to work together and deal with barriers that affect gold export competitiveness.

The international market is full of conscious customers as the world of luxury jewellery is changing in important ways. Johannesburg once upon acclaimed 'city of gold', was known in terms of high-quality gold jewellery, and represented more exceptional gold jewellery luxury with lasting value. Increasingly, the gold jewellery brands that came out of it have always represented authentic luxury with a deeply recognisable legacy of craftsmanship and quality. Thus, the government of South Africa has the primary responsibility to put a cocktail of gold jewellery export incentives and set financing mechanisms that promote the processing of gold jewellery brands that sustainably maintain the 'Made in South Africa' patents. There is the logic of a growing sensibility among gold jewellery users and fashion enthusiasts to selectively focus on gold jewellery from Johannesburg because they trust and know that it is of high quality and it is authentic gold.

The findings from the models have also shown that the level of internationalisation has a strong bearing on the positive or negative impact on companies' performance - with those companies that produce high-technology driven products, having a greater chance of success in the export market. Consequently, incorporating technology should be part of the gold jewellery sector's 
evolution, so that these firms remain competitive and manage to navigate intense competition in the export market. The whole idea is that metal processing is evolving and firms in developing countries, such as South Africa, have to adapt and modify their processes so that they catch up with the rest of the world.

There is a strong argument that internationalisation performs better where there is the demonstrable capacity to generate revenue and growth, but more importantly, the accumulation of assets also increases the value of the firm. Imperatively, the issue of research and development of markets is key. This should be complemented by the supply of quality products and also the consistent monitoring of market tastes and preferences, which is part of market intelligence. The firms that keep pace with changing market demands and quickly adapt are more likely to survive in internationalisation than those that remain dogmatic and hence achieve poor performance in generating revenue and growth.

This study has also provided a better understanding of internationalisation models by providing conceptual evidence that firms should differentiate between local products' demand and international products' demand, and that the levels of competitiveness vary in respect of local and global markets. The international market is highly competitive and demands more in so far as product quality and price competitiveness are concerned. Thus, firms need to pursue differentiationwith the local market, needing a separate strategy while the international market needs its own. The fact is, any gold jewellery firm should rely upon a multiplicity of products, which reduce the risks, associated with products rejection, and to grow, jewellery firms should be able to diversify even the markets apart from the products in the international market.

Limitations of the study. The main limitations of this study is that it only covered one geographical area, that the city of Johannesburg in South Africa. Deeper and more insights could have been obtained had the study considered the activities of jewellery exporters nationally and beyond.

Prospects for further research. This study recommends that future studies could potentially be carried out to determine the measures, used by competitor countries to stimulate exports of gold jewellery, and identifying other stimuli that can be used to motivate gold jewellery manufacturers to consider exporting.

\section{Conclusion}

Based on the review of the models on internationalisation, discussed in this paper, and the concurrent discussion of the findings, it is imperative to assert, that firms in Johannesburg should pursue internationalisation with an open mind to the demands of the market and their responsibilities as gold jewellery manufacturers. It is without a doubt, that at the strategic level, firms need to pursue a combination of one or two models in their approach to international markets. The gold jewellery companies enter the international market to grow and increase profits. They also enter that space as well as to satisfy the needs of their businesses as they expand to also reduce the risk of relying on the domestic market.

Technically, the international market and expansion thereof help to hedge local production against risks from domestic market failures. Hence, those firms in the gold jewellery sector that pursue a differentiation strategy of the markets and strategically hedge themselves by including in their growth approach, the international markets, have higher chances of success. The models have indeed shed light on the importance of technology that is central to the production of quality products - and this should be adapted to keep pace with the changing environment. Nevertheless, within highly competitive international markets, the gold jewellery sector cannot rely only on internationalisation, the outbreak of Covid-19 in 2020 has provided many lessons on the need to also strengthen the local market that keeps the firm afloat in times of economic turmoil - and this should be part of the strategic business decisions that the firms have to make and implement. As such, various aspects of different internationalisation models could be incorporated in a particular firm's businesses model to ensure that its products reach the international markets and are competitive. The barriers that exist in the industry require both private sector and public sector involvement in dealing with them, without which, the gold jewellery manufacturing sector will continue to experience slow growth. 


\section{References}

[1] Manzi, M. J. (2019). The influence of export incentives on gold jewellery manufacturers' decision to export: the case of selected Gauteng manufacturers. Cape Peninsula University of Technology, 109.

[2] Leonidou, L. C., Katsikeas, C. S., Palihawadana, D., Spyropoulou, S. (2007). An analytical review of the factors stimulating smaller firms to export. International Marketing Review, 24 (6), 735-770. doi: http://doi.org/10.1108/02651330710832685

[3] Da Silva, M. D. R. P. P. (2006). From dynamism to dormancy: the jewellery industry in Johannesburg: 1925-2003.

[4] Van der Wath, N. (2019). A total return index for South Africa. Available at: http://2015.essa.org.za/fullpaper/essa_2868.pdf. Last accessed: 16.03.2021

[5] Haugen, H. Ø. (2017). Petty commodities, serious business: the governance of fashion jewellery chains between China and Ghana. Global Networks, 18 (2), 307-325. doi: http://doi.org/10.1111/glob.12164

[6] Bryman, A., Bell, E. (2007). Business research methods. Oxford: Oxford University Press, 785.

[7] Neuman, W. L. (2006). Social research methods - qualitative and quantitative approaches. Pearson Education, Inc., 592.

[8] Vahlne, J.-E., Johanson, J. (2017). From internationalization to evolution: The Uppsala model at 40 years. Journal of International Business Studies, 48 (9), 1087-1102. doi: http://doi.org/10.1057/s41267-017-0107-7

[9] Akpinar, M., Scott, A. (2009). Internationalization vs. Diversification: A Study on the Drivers of Growth Strategies. Journal of Global business issues, 3 (2), 1-6.

[10] Johanson, J., Vahlne, J.-E. (1977). The Internationalization Process of the Firm - A Model of Knowledge Development and Increasing Foreign Market Commitments. Journal of International Business Studies, 8 (1), 23-32. doi: http://doi.org/10.1057/ palgrave.jibs.8490676

[11] Johanson, J., Wiedersheim-Paul, F. (1975). The internationalization of the firm ? Four swedish cases. Journal of Management Studies, 12 (3), 305-323. doi: http://doi.org/10.1111/j.1467-6486.1975.tb00514.x

[12] Geringer, J. M., Hebert, L. (1989). Control and Performance of International Joint Ventures. Journal of International Business Studies, 20 (2), 235-254. doi: http://doi.org/10.1057/palgrave.jibs.8490359

[13] Morgan-Thomas, A., Jones, M. V. (2009). Post-entry Internationalization Dynamics. International Small Business Journal: Researching Entrepreneurship, 27 (1), 71-97. doi: http://doi.org/10.1177/0266242608098347

[14] Hollensen, S. (2007). Global marketing: A decision-oriented approach. Pearson education, Upper Saddle River.

[15] Kotler, P., Armstrong, G., Harris, L. C., Piercy, N. (2014). Principles of Marketing. Financial times/Prentice Hall.

[16] Deresky, H. (2005). International Management: Managing across borders and cultures. Prentice Hall Published, 504.

[17] Ansoff, H. I. (1987). Corporate Strategy. London: Penguin, 116.

[18] Morgan, R. E., Katsikeas, C. S. (1997). Theories of international trade, foreign direct investment and firm internationalization: a critique. Management Decision, 35 (1), 68-78. doi: http://doi.org/10.1108/00251749710160214

[19] De Chiara, A. (2017). Stakeholder engagement in sustainability innovation: Experiences in the jewellery business. Innovating in practice. Cham: Springer, 439-459.

[20] Satsangi, P. (2013). Exports of Gems and Jewellery from India - SWOPT analysis, 2.

[21] Chellam, K. C. (2018). Jewellery industry in India. International Journal of Marketing and Technology, 8 (2), 1-18.

[22] Qureshi, M. S., Wan, G. (2008). Trade Expansion of China and India: Threat or Opportunity? World Economy, 31 (10), $1327-1350$. doi: http://doi.org/10.1111/j.1467-9701.2008.01131.x

[23] Whitelock, J. (2002). Theories of internationalisation and their impact on market entry. International Marketing Review, 19 (4), 342-347. doi: http://doi.org/10.1108/02651330210435654

[24] Onkvisit, S., Shaw, J. J. (2004). International marketing: Analysis and strategy. Psychology Press, 594.

[25] Gemser, G., Brand, M., Sorge, A. (2012). Internationalisation strategies of technology-driven small- and medium-sized enterprises. Technology Analysis \& Strategic Management, 24 (3), 311-326. doi: http://doi.org/10.1080/09537325.2012.655418

[26] Ratten, V. (2006). Policy drivers of international entrepreneurship in Europe. EuroMed Journal of Business, 1 (2), $15-28$. doi: http://doi.org/10.1108/14502190610750144

[27] Bell, J., Loane, S. (2010). "New-wave" global firms: Web 2.0 and SME internationalisation. Journal of Marketing Management, 26 (3-4), 213-229. doi: http://doi.org/10.1080/02672571003594648

[28] Da Silva, M. (1999). The jewellery industry in South Africa. Urban Forum, 10 (2), 217-234. doi: http://doi.org/10.1007/ bf03036619

[29] Central Intelligence Agency (2020). The World Factbook Field Listing: Exports - Commodities.

[30] Bhattacharya, J. (2015). Beyond the Glitterati: The Indian and Chinese Jewellers of Little India. Singapore: Indian and Chinese Immigrant Communities: Comparative Perspectives, 91.

[31] Hancok, T. (2019). Demand for gold jewellery up in SA, but imports favoured. Available at: https://www.miningweekly.com/ print-version/demand-for-gold-jewellery-up-in-sa-but-imports-favoured-2019-06-28 
[32] Wilkinson, T., Brouthers, L. E. (2006). Trade promotion and SME export performance. International Business Review, 15 (3), 233-252. doi: http://doi.org/10.1016/j.ibusrev.2006.03.001

[33] Ogasavara, M. H., Boehe, D. M., Barin Cruz, L. (2016). Experience, resources and export market performance. International Marketing Review, 33 (6), 867-893. doi: http://doi.org/10.1108/imr-10-2013-0247

[34] Miocevic, D., Crnjak-Karanovic, B. (2012). Global mindset - a cognitive driver of small and medium-sized enterprise internationalization. EuroMed Journal of Business, 7 (2), 142-160. doi: http://doi.org/10.1108/14502191211245589

[35] Drachal, K. (2014). Property prices and regional labor markets in Poland. Singidunum Journal of Applied Sciences, 11 (1), 5-15. doi: http://doi.org/10.5937/sjas11-4650

[36] Hollensen, S., Boyd, B., Ulrich, A. M. D. (2011). The Choice of Foreign Entry Modes in a Control Perspective. IUP Journal of Business Strategy, 8 (4), 7-31.

[37] Dunning, J. H. (1988). The theory of international production. The International Trade Journal, 3 (1), 21-66. doi: http:// doi.org/10.1080/08853908808523656

[38] Daszkiewicz, N., Wach, K. (2012). Internationalization of SMEs: Context, models and implementation. Internationalization of SMEs. Context, Models and Implementation. Gdańsk University of Technology Publishers.

[39] Dunning, J. H. (2000). The eclectic paradigm as an envelope for economic and business theories of MNE activity. International Business Review, 9 (2), 163-190. doi: http://doi.org/10.1016/s0969-5931(99)00035-9

[40] Hermannsdottir, A. (2008). Theoretical underpinnings of the internationalization process. Reykjavik: Institute of Business Research, University of Iceland School of Business. Working Paper Series W08:02. doi: http://doi.org/10.13140/ RG.2.2.24894.59203

[41] Klein, S., Frazier, G. L., Roth, V. J. (1990). A Transaction Cost Analysis Model of Channel Integration in International Markets. Journal of Marketing Research, 27 (2), 196-208. doi: http://doi.org/10.1177/002224379002700207

[42] Katsikeas, C. S. (1996). Ongoing export motivation: differences between regular and sporadic exporters. International Marketing Review, 13 (2), 4-19. doi: http://doi.org/10.1108/02651339610115737

[43] Leonidou, L. C., Katsikeas, C. S., Palihawadana, D., Spyropoulou, S. (2007). An analytical review of the factors stimulating smaller firms to export. International Marketing Review, 24 (6), 735-770. doi: http://doi.org/10.1108/02651330710832685

[44] Hill, C. W. L. (2013). International business: competing in the global marketplace. New York: McGraw-Hill/Irwin.

[45] Madanoglu, M., Alon, I., Shoham, A. (2017). Push and pull factors in international franchising. International Marketing Review, 34 (1), 29-45. doi: http://doi.org/10.1108/imr-03-2015-0037

[46] Zafarullah, M., Ali, M., Young, S. (1997). The Internationalization of the Small Firm in Developing Countries - Exploratory Research from Pakistan. Journal of Global Marketing, 11 (3), 21-40. doi: http://doi.org/10.1300/j042v11n03_03

[47] Francis, J., Collins-Dodd, C. (2004). Impact of export promotion programs on firm competencies, strategies and performance. International Marketing Review, 21 (4/5), 474-495. doi: http://doi.org/10.1108/02651330410547153

[48] Diamantopoulos, A., Hart, S. (1993). Linking market orientation and company performance: preliminary evidence on Kohli and Jaworski's framework. Journal of strategic marketing, 1 (2), 93-121. doi: http://doi.org/10.1080/09652549300000007

[49] De Falco, S. E., Simoni, M. (2014). The Effect of Public Export Incentives on Italian Textile and Fashion SMEs. International Studies of Management \& Organization, 44 (1), 70-83. doi: http://doi.org/10.2753/imo0020-8825440105

[50] Wagner, J. (2012). Exports, imports and firm survival: first evidence for manufacturing enterprises in Germany. Review of World Economics, 149 (1), 113-130. doi: http://doi.org/10.1007/s10290-012-0141-2

[51] Gereffi, G., Humphrey, J., Sturgeon, T. (2005). The governance of global value chains. Review of International Political Economy, 12 (1), 78-104. doi: http://doi.org/10.1080/09692290500049805

[52] Xue, L. (1997). A historical perspective of China's innovation system reform: a case study. Journal of Engineering and Technology Management, 14 (1), 67-81. doi: http://doi.org/10.1016/s0923-4748(97)00002-7

[53] Gereffi, G., Memedovic, O. (2003). The global apparel value chain: What prospects for upgrading by developing countries. Vienna: United Nations Industrial Development Organization, 2009-2012. doi: http://doi.org/10.2139/ssrn.424560

Received date 18.05.2021

(C) The Author(s) 2021

Accepted date 06.07.2021

Published date 30.07.2021

This is an open access article under the Creative Commons CC BY license

How to cite. Mugobo, V., Manzi, M. J. (2021). Internationalisation models and trajectories of gold jewellery in Johannesburg: a conjectural discursive approach. EUREKA: Social and Humanities, 4, 9-25. doi: http://doi.org/10.21303/2504-5571.2021.001833 